\title{
Ventricular Arrhythmia With Cessation of Infliximab in a Patient With Ankylosing Spondylitis
}

\author{
Ankilozan Spondilitli Bir Hastada Infliksimabın Kesilmesiyle Olușan Ventriküler Aritmi
}
Özgür Ulaș Özcan ${ }^{1}$, Didem Sezgin Özcan², Cemile Sevgi Polat², Nil Özyüncü1, Çetin Erol ${ }^{1}$

Ankara University, Department of Cardiology, Ankara, Turkey Ankara Physical Medicine and Rehabilitation Education and Research Hospity
Ankara, Turkey

Received : June 02,2015 • Accepted: Aug 04,2015

\section{Corresponding Author}

Ozgur Ulas Ozcan, MD Tel: +90 5057077670

E-mail: ozgurulasozcan@yahoo.com.tr

Ankara University, School of Medicine, Department of Cardiology, Ankara-TURKEY

Infliximab is an anti-tumor necrosis factor alpha agent, which is indicated for the treatment of resistant ankylosing spondylitis (AS). We presented a patient with AS who developed ventricular tachycardia after premature cessation of infliximab. Ventricular tachycardia did not recur after restarting of infliximab treatment. This case report remarked the significance of the suppression of inflammation in AS since the subclinical ventricular involvement may potentially lead to the fatal arrhythmias.

Key Words: Arrhythmia, Arthritis, Seronegative Spondyloarthropathy, Syncope, Tumor Necrosis Factor Alpha

İnfliksimab dirençli ankilozan spondilit (AS) tedavisinde endikasyonu bulunan bir anti-tümör nekroz faktör alfa ajanıdır. İnfliksimabın erken kesilmesi sonucu ventriküler tașikardi gelișen bir hasta sunuyoruz. Infliksimab tedavisinin tekrar bașlanmasıyla ventriküler tașikardi tekrarlamamıștır. Bu vaka takdimi AS hastalarında inflamasyonun, subklinik ventriküler tutulumun potansiyel olarak ölümcül aritmilere yol açabilmesi nedeniyle, baskılanmasının önemini vurgulamaktadır.

Anahtar Sözcükler: Aritmi, Artrit, Senkop, Seronegatif Spondiloartropati, Tümör Nekroz Faktör Alfa

Ankylosing spondylitis (AS) is a chronic autoimmune inflammatory disease affecting the axial and peripheral skeleton (1). Increased burden of cardiovascular disease is an indisputable fact of the autoimmune inflammatory diseases although such relation has been less clear among patients with AS (2-4). Increased inflammatory activity may involve the pathogenesis of various cardiovascular disorders as well as arrhythmias $(5,6)$.

In patients with AS, administration of infliximab has been reported to be associated with ventricular arrhythmia (7). However, incidence of ventricular arrhythmia with premature cessation of infliximab has not previously been reported. We presented a patient with AS who suffered from ventricular tachycardia after premature cessation of infliximab.

\section{Case Report}

A 42-year-old woman was admitted to the emergency department with an episode of syncope. She had diagnosed with AS 9 years ago and was scheduled for infliximab therapy. Treatment with non-steroidal antiinflammatory drugs and sulfasalazine over 6 months was ineffective for reduction of pain or improvement of physical activity and spinal mobility. Doses of infliximab $5 \mathrm{mg} / \mathrm{kg}$ were administered intravenously at weeks 0,2 and 6. However, she discontinued therapy intentionally after third dose because of dizziness, headache and unusual tiredness after drug infusion. On physical examination blood pressure was $80 / 50 \mathrm{mmHg}$, heart rate was 170/min. Electrocardiogram revealed wide QRS tachycardia (Figure 1) and direct current cardioversion was performed. She had no history of any cardiovascular disease, hypertension or diabetes mellitus. Serum chemistry 
panel revealed $\mathrm{Na}$ of $139 \mathrm{mg} / \mathrm{dL}, \mathrm{K}$ of $4.5 \mathrm{mg} / \mathrm{dL}$, glucose of $115 \mathrm{mg} / \mathrm{dL}$ and $\mathrm{Ca}$ of $9.8 \mathrm{mg} / \mathrm{dL}$. Urinalysis and liver functions were normal. Serum thyroid stimulating hormone level was within normal range (3.2 $\mathrm{mIU} / \mathrm{L})$. Level of high sensitive-CRP (hs-CRP) was $16.2 \mathrm{mg} / \mathrm{L}$ and erythrocyte sedimentation rate (ESR) was $43 \mathrm{~mm} / \mathrm{h}$.

Transthoracic echocardiography revealed normal left ventricular systolic functions, wall motions, ascending aorta diameter and aortic valve. Impaired relaxation of the left ventricle, mild mitral and tricuspid regurgitation were also reported. A 24-h rhythm Holter monitoring revealed a $16 \%$ of ventricular ectopic systole (VES) burden with episodes of monomorphic ventricular tachycardia (Figure 2). Coronary angiography was performed due to suspected acute coronary event to rule out significant coronary stenosis and demonstrated the patency of epicardial coronary arteries.

After the initial tests, we started the treatment with intravenous infliximab $5 \mathrm{mg} / \mathrm{kg}$ every 6 weeks. She was asymptomatic two months later at follow-up visit. Plasma hs-CRP was $3.7 \mathrm{mg} / \mathrm{L}$ and ESR was $14 \mathrm{~mm} / \mathrm{h}$. Reduced frequency of VES (VES burden $2 \% / 24 \mathrm{~h}$ ) with few couplets were seen on 24-h rhythm Holter monitoring (Figure 3).

\section{Discussion}

The typical cardiac complications of AS are aortic valve regurgitation with ascending aortitis and conduction system blocks (8). Infliximab, a murine monoclonal antibody against human tumor necrosis factor alpha (TNF- $\alpha$ ), has anti TNF effect (9). Infliximab is used for the treatment of AS which is resistant to nonsteroidal anti-inflammatory drugs and sulfasalazine (10).

Chronic high-grade systemic inflammation is a characteristic of AS. Increased levels of pro-inflammatory cytokines may promote cardiac myocyte hypertrophy or apoptosis, extracellular

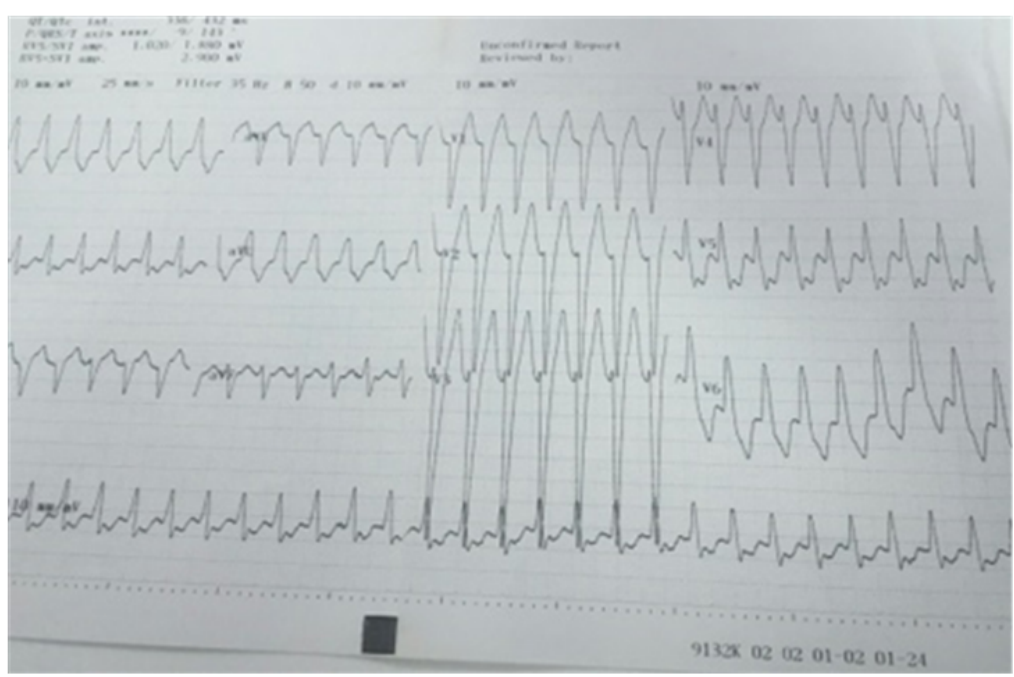

Figure 1: Electrocardiogram of the patient on admission revealed a wide QRS tachycardia.

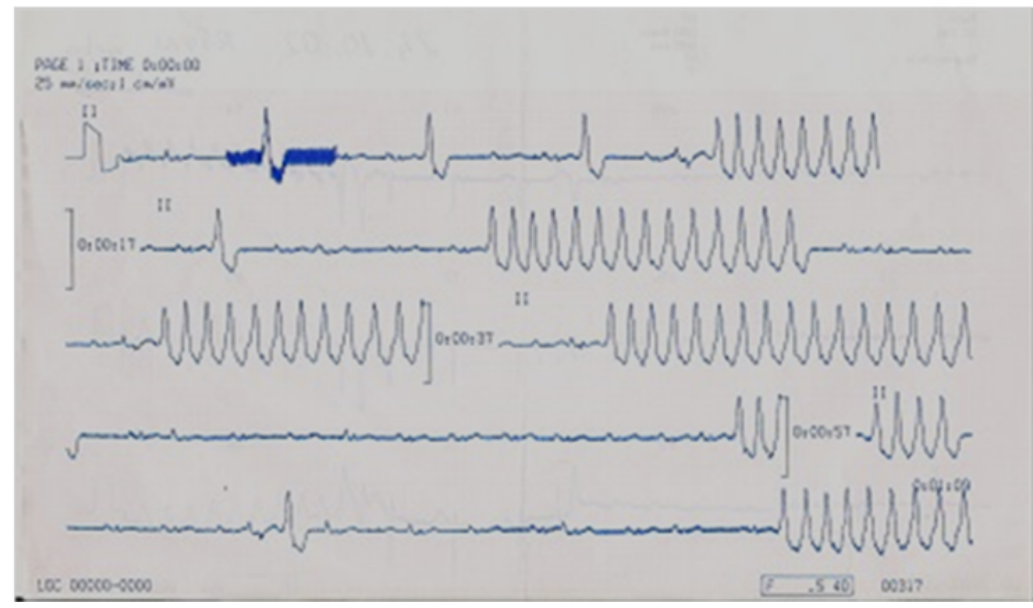

Figure 2: Episodes of monomorphic ventricular tachycardia were seen on 24-h rhythm Holter monitoring.

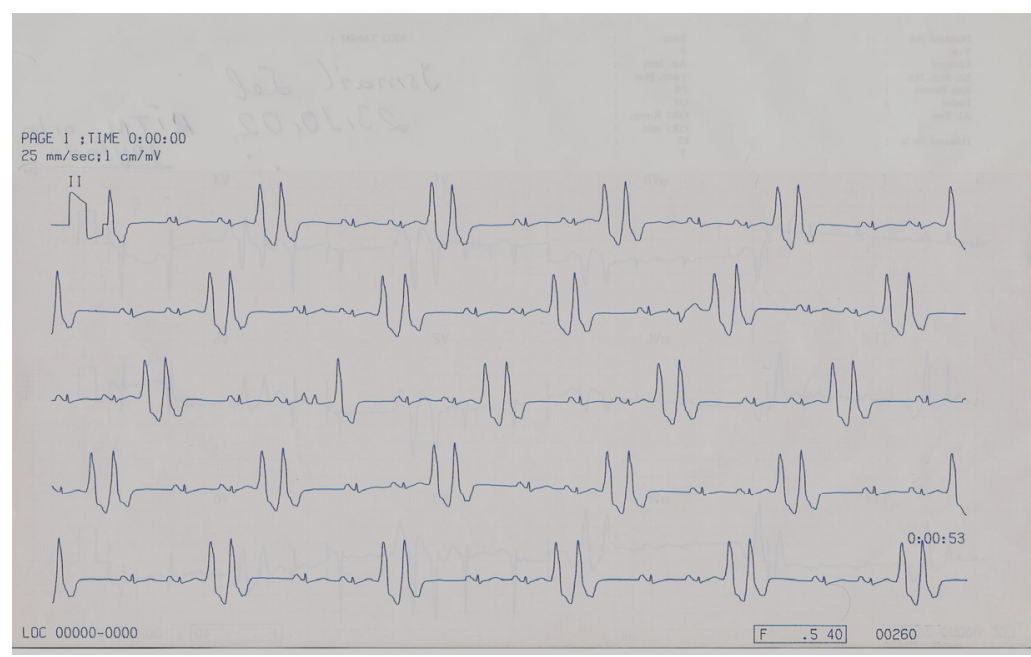

Figure 3: Couplets without any episode of ventricular tachycardia were reported on 24-h rhythm Holter monitoring at second month visit 
matrix remodeling and subsequent myocardial fibrosis. An autopsy study demonstrated fibrosis of myocardium in AS (11). The development of fibrosis may serve as a substrate for reentrant arrhythmias (12). Three-fold increased risk of ventricular tachycardia was demonstrated with high C-reactive protein levels (6). Treatment with TNF- $\alpha$ antagonist has been found favorable with respect to improvement of cardiovascular status of the patients with inflammatory arthritis (13). Suppression of the inflammatory status may improve

\section{KAYNAKLAR}

1. Papagoras C, Voulgari PV, Drosos AA. Atherosclerosis and cardiovascular disease in the spondyloarthritides, particularly ankylosing spondylitis and psoriatic arthritis. Clin Exp Rheumatol 2013;31:612-20.

2. Roifman I, Beck PL, Anderson TJ et al. Chronic inflammatory diseases and cardiovascular risk: a systematic review. Can J Cardiol 2011;27:174-82.

3. Peters MJ, van der Horst-Bruinsma IE, Dijkmans BA et al. Cardiovascular risk profile of patients with spondylarthropathies, particularly ankylosing spondylitis and psoriatic arthritis. Semin Arthritis Rheum 2004;34:585-92.

4. Kang JH, Chen YH, Lin HC. Comorbidity profiles among patients with ankylosing spondylitis: a nationwide population-based study. Ann Rheum Dis 2010;69:1165-8.

5. Lagrand WK, Visser CA, Hermens WT et al. C-reactive protein as a cardiovascular risk factor: more than an epiphenomenon? Circulation 1999;100:96-102. repolarization abnormalities and thereby may correct pro-arrhythmic milieu. In a previous study, infliximab therapy reduced the corrected QT interval on electrocardiogram (14).

The typical cardiovascular complications of AS are associated with the involvement of ascending aorta and aortic root, which may lead to valvular insufficiency (8). Ventricular arrhythmia may rarely occur due to ventricular inflammation and fibrosis (11, 12). Cardiac involvement may usually be occult in patients with AS,

6. Blangy H, Sadoul N, Dousset B et al. Serum BNP, hs-C-reactive protein, procollagen to assess the risk of ventricular tachycardia in ICD recipients after myocardial infarction. European pacing, arrhythmias, and cardiac electrophysiology : journal of the working groups on cardiac pacing, arrhythmias, and cardiac cellular electrophysiology of the European Society of Cardiology. Europace 2007;9:724-9.

7. Lazzerini PE, Acampa M, Hammoud M et al. Arrhythmic risk during acute infusion of infliximab: a prospective, single-blind, placebo-controlled, crossover study in patients with chronic arthritis. J Rheumatol 2008;35:1958-65.

8. Brunner F, Kunz A, Weber $U$ et al. Ankylosing spondylitis and heart abnormalities: do cardiac conduction disorders, valve regurgitation and diastolic dysfunction occur more often in male patients with diagnosed ankylosing spondylitis for over 15 years than in the normal population? Clin Rheumatol 2006;25:24-9.

9. Knight DM, Trinh $\mathrm{H}$, Le $\mathrm{J}$ et al. Construction and initial characterization of a mouse-human chimeric anti-TNF antibody. Mol Immunol 1993;30:1443-53. until symptoms of aortic regurgitation or bradyarrhythmia develops. Infliximab infusion may increase the risk of arrhythmias. However, in this case, premature cessation of infliximab eventuated in development of ventricular arrhythmia, which may be triggered by subclinical ventricular inflammation. This report remarked the significance of the suppression of inflammation in AS, which may prevent potentially fatal events due to subclinical ventricular involvement.

10. Maxwell LJ, Zochling J, Boonen A et al. TNF-alpha inhibitors for ankylosing spondylitis. Cochrane Database Syst Rev 2015;4:CD005468.

11. Brewerton DA, Gibson DG, Goddard $\mathrm{DH}$ et al. The myocardium in ankylosing spondylitis. A clinical, echocardiographic, and histopathological study. Lancet 1987;1:995-8.

12. Sano K, Watanabe E, Hayano J et al. Central sleep apnoea and inflammation are independently associated with arrhythmia in patients with heart failure. Eur J Heart Fail 2013;15:1003-10.

13. Tam LS, Kitas GD, Gonzalez-Gay MA. Can suppression of inflammation by antiTNF prevent progression of subclinical atherosclerosis in inflammatory arthritis? Rheumatology 2014;53:1108-19.

14. Senel S, Cobankara V, Taskoylu O et al. Effect of infliximab treatment on QT intervals in patients with ankylosing spondylitis. J Investig Med 2011;59:12735. 
